\title{
Intravenous tissue plasminogen activator and size of infarct, left ventricular function, and survival in acute myocardial infarction
}

\author{
Frans Van de Werf, Alfred E R Arnold \\ For the European Cooperative Study Group for recombinant tissue type plasminogen activator
}

\section{Abstract}

Study objective-To assess effect of intravenous recombinant tissue type plasminogen activator on size of infarct, left ventricular function, and survival in acute myocardial infarction.

Design-Double blind, randomised, placebo controlled prospective trial of patients with acute myocardial infarction within five hours after onset of symptoms.

Setting-Twenty six referral centres participating in European cooperative study for recombinant tissue type plasminogen activator.

Patients - Treatment group of 355 patients with acute myocardial infarction allocated to receive intravenous recombinant plasminogen activator. Controls comprised 366 similar patients allocated to receive placebo.

Intervention-All patients were given aspirin $250 \mathrm{mg}$ and bolus injection of 5000 IU heparin immediately before start of trial. Patients in treatment group were given $100 \mathrm{mg}$ recombinant tissue plasminogen activator over three hours $(10 \mathrm{mg}$ intravenous bolus, $50 \mathrm{mg}$ during one hour, and $40 \mathrm{mg}$ during next two hours) by infusion. Controls were given placebo by same method. Full anticoagulation treatment and aspirin were given to both groups until angiography (10-22 days after admission). $\beta$ Blockers were given at discharge.

End point-Left ventricular function at 10-22 days, enzymatic infarct size, clinical course, and survival to three month follow up.

Measurements and main results-Mortality was reduced by $51 \%$ (95\% confidence interval -76 to 1$)$ in treated patients at 14 days after start of treatment and by $36 \%$ ( -63 to 13$)$ at three months. For treatment within three hours after myocardial infarction mortality was reduced by $82 \%(-95$ to -31$)$ at 14 days and by $59 \%(-83$ to -2$)$ at three months. During 14 days in hospital incidence of cardiac complications was lower in treated patients than controls (cardiogenic shock, $2.5 \%$ v $6.0 \%$; ventricular fibrillation, $3.4 \% v 6.3 \%$; and pericarditis, $6.2 \% v$ $11.0 \%$ respectively), but that of angioplasty or artery bypass, or both was higher $(15.8 \% v 9 \cdot 6 \%)$ during the first three months. Bleeding complications were commoner in treated than untreated patients. Most were minor, but $1.4 \%$ of treated patients had intracranial haemorrhage within three days after start of infusion.

Enzymatic size of infarct, determined by $\alpha$ hydroxybutyrate dehydrogenase concentrations, was less $(20 \%, 2 p=0.0018)$ in treated patients than in controls. Left ventricular ejection fraction was $2 \cdot 2 \%$ higher (0.3 to 4.0$)$ and end diastolic and end systolic volumes smaller by $6.0 \mathrm{ml}(-0.2$ to -11.9$)$ and $5.8 \mathrm{ml}$ $(-0.9$ to -10.6$)$, respectively, in treated patients.

Conclusion-Recombinant tissue type plasminogen activator with heparin and aspirin reduces size of infarct, preserves left ventricular function, and reduces complications and death from cardiac causes but at increased risk of bleeding complications.

\section{Introduction}

Intravenous thrombolysis is becoming widely accepted as a standard treatment for acute myocardial infarction. Nevertheless, the effects on early and late survival, site of infarct, and left ventricular function are variable and not always consistent. ${ }^{1-15}$ Furthermore, in most trials thrombolytic treatment has been associated with an increased risk of bleeding.

Newer thrombolytic agents are being evaluated for intravenous use in the acute stage of myocardial infarction..$^{10-18}$ Among these, recombinant tissue plasminogen activator has a considerably higher specificity for fibrin and a greater thrombolytic efficacy than streptokinase. ${ }^{1718}$ To study the effect of intravenous recombinant tissue plasminogen activator on size of infarct, left ventricular function, and follow up a large prospective, placebo controlled, double blind, multicentre trial was launched by the European Co-operative Study Group for recombinant tissue plasminogen activator in May 1986; the main results are presented here.

\section{Patients and methods}

Patients between 21 and 71 years old who had chest pain typical of myocardial ischaemia for at least 30 minutes were eligible for the trial, provided that experimental treatment could be started within five hours after the onset of symptoms. ST segment elevation of at least $2 \mathrm{~mm}$ (measured 60 milliseconds after the J point) in two or more limb leads or leads V5 and V6 had to be present or an elevation of $3 \mathrm{~mm}$ in two or more precordial leads. Patients with ST segment depression of $2 \mathrm{~mm}$ or more in two precordial leads together with ST segment elevation of a least $1 \mathrm{~mm}$ in two limb leads or leads V5 and V6, indicating infarction of the posterior wall, were also included.

Exclusion criteria were: oral anticoagulation treatment, recent major trauma, prolonged or traumatic heart massage, artificial respiration, transmural myocardial infarction during the preceding two weeks, previous myocardial infarction at the same site or previous coronary artery bypass surgery, history of cerebrovascular accident or gastrointestinal bleeding during the previous three months, major hepatic or renal disease, known proliferative diabetic retinopathy, bleeding disorders and other diseases with an expected survival of less than two years, and expected problems with catheterisation of the heart or with follow up.

Consenting patients were registered with a central telephone allocation service. Allocation to receive either recombinant tissue plasminogen activator or placebo was made double blind during the same telephone call by opening a sealed envelope containing the treatment number corresponding to a treatment package at the clinic. Randomisation was in blocks of four patients and was balanced for each of the 26 participating hospitals (see appendix).

\section{TREATMENT}

All patients received $250 \mathrm{mg}$ aspirin and a bolus injection of 5000 IU heparin immediately before the start of the trial treatment. Patients in the treatment group were given $10 \mathrm{mg}$ intravenous bolus of predominantly single chain recombinant tissue plasminogen activator (G-11044, Genentech supplied by Boehringer Ingelheim International) followed by 50 $\mathrm{mg}$ during one hour and $40 \mathrm{mg}$ during the next two hours given with an infusion pump; in the other group 
(controls) placebo was given in exactly the same way. After the start of infusion all patients were treated with intravenous heparin $1000 \mathrm{IU} /$ hour and aspirin 75-125 mg orally every other day until angiography. After three days heparin could be replaced by oral anticoagulants. Any other treatment was given only if clinically indicated. At discharge patients were given a $\beta$ blocker, unless this was contraindicated.

\section{LABORATORY ANALYSES}

Samples of blood for assessment of the activities of cardiac enzymes locally and of plasma $\alpha$ hydroxybutyrate dehydrogenase centrally were collected before the start of the trial treatment and after $12,24,36,48$, 72 , and 96 hours. Cumulative release of plasma $\alpha$ hydroxybutyrate dehydrogenase was calculated in the core laboratory for enzyme determinations as described before ${ }^{1920}$ and expressed in U/l of plasma. The value at 72 hours was used as an estimate of the size of infarct. In patients in whom data was incomplete this value was estimated by extrapolation of the data at 48 or 36 hours, or from a single value of the activity determined after at least 24 hours, or from serum aspartate aminotransferase activity, which was determined locally. In a predetermined subset of patients samples of blood for assays of coagulation and fibrinolysis were obtained before the start of infusion and at two and 24 hours afterwards. The concentrations of fibrinogen and fibrin(ogen) degradation products were estimated centrally. ${ }^{18}$

\section{CARDIAC CATHETERISATION}

Coronary arteriography and left ventriculography were done 10-22 days after the acute event with either the Sones or the Judkins technique and recorded on 35 mm $x$ ray film. Each hospital chose a time interval of 4 days in which angiography had to be performed, at 10$14,12-16,14-18,16-20$, or $18-22$ days after the allocation of patients. All films were examined centrally by the angiography assessment group, which identified the infarcted vessel with the help of the electrocardiogram, assessed its patency according to the thrombolysis in myocardial infarction study, ${ }^{17}$ and confirmed that the technical quality of the left ventricular angiograms was adequate for quantitative measurements. Left ventricular end systolic and end diastolic volumes and ejection fraction were measured by the central core laboratory from the $30^{\circ}$ right anterior oblique projection of the angiogram by the area-length method. Internal calibration was provided by a cast of known volume filmed at the time of the angiogram.

\section{STATISTICAL ANALYSES}

Calculation of the size of the trial was based on the left ventricular ejection fraction at 10-22 days: to detect a relative $5 \%$ difference in ejection fraction between the two treatment groups with $80 \%$ power at a 0.05 level of significance 300 patients whose angiograms were analysable were needed in each group. Assuming that missing and non-analysable angiograms might be predicted in $15 \%$ of the patients, we calculated that 700 patients would be needed.

Collection and analysis of data were performed by an autonomous data centre, which was independent of the investigators and the sponsor. All registered patients were included in the analysis even if the experimental treatment had not been started. All assessments were performed without knowledge of the treatment allocation. Continuous variables are reported as median and $90 \%$ range values. When the distribution of a variable permitted, the difference between means and $95 \%$ confidence intervals were calculated..$^{21}$ Results for release of myocardial $\alpha$ hydroxybutyrate dehydrogenase at 72 hours were analysed by the Mann-
Whitney rank sum test. The ratio of proportions (rate ratio) and its $95 \%$ confidence interval were calculated according to Miettinen and Nurminen, ${ }^{22}$ in addition to the $\chi^{2}$ test.

\section{Results}

Between May 1986 and November 1987,721 patients were randomised in the 26 participating hospitals: 366 were allocated to receive placebo and 355 to receive plasminogen activator. In eight patients the trial treatment was not given. Three patients violated the protocol: one in each group refused consent after being allocated and one control was given streptokinase instead of the trial treatment. In five patients the trial treatment was not given for clinical reasons normalisation of ST-T changes in two controls and cardiac arrest and death, diabetic retinopathy, and a severe haematoma due to arterial puncture in three patients allocated to receive plasminogen activator The eight patients were included in the analysis according to their allocation to treatment. Two patients in the placebo group were allocated, although coronary artery bypass had been performed previously. Baseline characteristics on admission were similar in the two groups (table I).

TABLE I-Baseline characteristics at admission

\begin{tabular}{|c|c|c|}
\hline & $\begin{array}{l}\text { Placebo } \\
(\mathrm{n}=366)\end{array}$ & $\begin{array}{l}\text { Recombinant } \\
\text { plasminogen } \\
\text { activator } \\
(\mathbf{n}=355)\end{array}$ \\
\hline Median $(\text { range })^{\star}$ age (years) & $58(43-69)$ & $58(41-69)$ \\
\hline No $(\%)$ men & $304(83)$ & $313(88)$ \\
\hline \multicolumn{3}{|l|}{ No (\%) with: } \\
\hline History of angina & $176(48)$ & $168(47)$ \\
\hline History of previous infarction & $26(7)$ & $27(8)$ \\
\hline Anterior infarction & $130(36)$ & $145(41)$ \\
\hline Electrocardiogram missing & $12(3)$ & $13(4)$ \\
\hline \multicolumn{3}{|l|}{ Median $(\text { range })^{\star}$ : } \\
\hline Heart rate $($ beats $/ \mathrm{min})$ & $72(49-102)$ & $72(50-104)$ \\
\hline Systolic blood pressure $(\mathrm{mm} \mathrm{Hg})$ & $130(90-170)$ & $130(90-180)$ \\
\hline Diastolic blood pressure (mm Hg) & $80(60-110)$ & $80(60-109)$ \\
\hline \multicolumn{3}{|l|}{ No (\%) with: } \\
\hline Mild heart failure (Killip class II) & $78(21)$ & $71(20)$ \\
\hline $\begin{array}{l}\text { Overt heart failure or shock (Killip } \\
\text { class III, IV) }\end{array}$ & $17(5)$ & $11(3)$ \\
\hline Ventricular fibrillation & $12(3)$ & $8(2)$ \\
\hline Third degree atrioventricular block & $11(3)$ & $11(3)$ \\
\hline $\begin{array}{l}\text { Median (range) delay from onset of } \\
\text { symptoms to treatment (hours) }\end{array}$ & $2 \cdot 8(1 \cdot 3 \cdot 4 \cdot 5)$ & $2 \cdot 9(1 \cdot 4-4 \cdot 6)$ \\
\hline
\end{tabular}

$\star 90 \%$ Range.

\section{CLINICAL COURSE}

Tables II and III summarise the clinical course during the stay in hospital and the three month follow up. During the first 14 days after allocation 21 out of the 366 controls $(5 \cdot 7 \%)$ died. The cause of death was cardiogenic shock (12), documented tamponade (six), sudden death (two), refractory ventricular fibrillation (one). After three months' follow up eight additional patients had died. Among the 355 patients allocated to receive plasminogen activator $10(2 \cdot 8 \%)$ died during the first two weeks, of whom one developed a third degree atrioventricular block and asystole and died before the infusion could be started. Another patient had intracranial bleeding and died in cardiogenic shock a few hours after the interruption of the heparin infusion and administration of tranexamic acid and plasma. Further causes of death were: cardiogenic shock (five patients) and ventricular fibrillation, electromechanical dissociation, and asystole (three) Eight additional patients died during the three month follow up, one of whom died from intracranial bleeding 12 hours after angioplasty and intravenous streptokinase. The reduction in mortality in the patients treated with plasminogen activator was $51 \%(95 \%$ confidence interval -76 to 1$)$ at 14 days and $36 \%(-63$ to 13) at three months (figure). In patients in whom the 
TABLE II-Clinical events during hospital stay in patients allocated to receive placebo or recombinant plasminogen activator. Figures are numbers (percentages) of patients

\begin{tabular}{|c|c|c|c|c|}
\hline & $\begin{array}{c}\text { Placebo } \\
(n=366)\end{array}$ & $\begin{array}{l}\text { Recombinant } \\
\text { plasminogen } \\
\text { activator } \\
(\mathrm{n}=355)\end{array}$ & $\begin{array}{l}\text { Rate } \\
\text { ratio }\end{array}$ & $\begin{array}{l}95 \% \\
\text { Confidence } \\
\text { interval }\end{array}$ \\
\hline $\begin{array}{l}\text { Bleeding complications and stroke } \\
\text { Documented haemorrhagic stroke } \\
\text { Documented non-haemorrhagic stroke } \\
\text { Non-documented stroke } \\
\text { Gastrointestinal bleeding } \\
\text { Retroperitoneal bleeding } \\
\text { Macroscopic haematuria } \\
\text { Haemoptysis } \\
\text { Epistaxis } \\
\text { Oropharyngeal bleeding } \\
\text { Pericardial bleeding } \\
\text { Genital bleeding } \\
\text { Local haematoma } \\
\text { Prolonged bleeding } \\
\text { Unexplained anaemia }\end{array}$ & $\begin{array}{l}27(7 \cdot 4) \\
2(0 \cdot 6) \\
4(1 \cdot 1) \\
1(0 \cdot 3) \\
4(1 \cdot 1) \\
2(0 \cdot 6) \\
1(0 \cdot 3) \\
6(1 \cdot 6) \\
9(2 \cdot 5) \\
2(0 \cdot 6) \\
3(0 \cdot 8)\end{array}$ & $\begin{array}{l}104(29 \cdot 3) \\
6(1 \cdot 7) \\
1(0 \cdot 3) \\
\\
5(1 \cdot 4) \\
2(0 \cdot 6) \\
16(4 \cdot 5) \\
4(1 \cdot 1) \\
4(1 \cdot 1) \\
7(2 \cdot 0) \\
2(0 \cdot 6) \\
68(19) \\
15(4 \cdot 2)\end{array}$ & 3.97 & $(2.69$ to 5.91$)$ \\
\hline $\begin{array}{l}\text { Blood transfusion } \\
\text { Cardiac complications: }\end{array}$ & $7(1.9)$ & $13(3 \cdot 7)$ & 1.92 & $(0.80$ to 4.62$)$ \\
\hline $\begin{array}{l}\text { Shock } \\
\text { Pulmonary oedema } \\
\text { Pericarditis } \\
\text { Ventricular fibrillation } \\
\text { Third degree atrioventricular block } \\
\text { Supraventricular tachyarrhythmia }\end{array}$ & $\begin{array}{l}22(6 \cdot 0) \\
24(6 \cdot 6) \\
40(11) \\
23(6 \cdot 3) \\
18(5 \cdot 0) \\
38(10 \cdot 4)\end{array}$ & $\begin{array}{r}9(2 \cdot 5) \\
22(6 \cdot 3) \\
22(6 \cdot 2) \\
12(3 \cdot 4) \\
11(3 \cdot 1) \\
27(7 \cdot 6)\end{array}$ & $\begin{array}{l}0.37 \\
0.95 \\
0.57 \\
0.54 \\
0.63 \\
0.73\end{array}$ & $\begin{array}{l}(0.17 \text { to } 0.83) \\
(0.54 \text { to } 1.64) \\
(0.35 \text { to } 0.93) \\
(0.28 \text { to } 1.05) \\
(0.31 \text { to } 1.29) \\
(0.46 \text { to } 1.17)\end{array}$ \\
\hline \multicolumn{5}{|c|}{ State at 14 days } \\
\hline $\begin{array}{l}\text { Deaths: } \\
\text { All patients } \\
\text { Patients treated }<3 \text { hours after onset of }\end{array}$ & $21(5 \cdot 7)$ & $10(2 \cdot 8)$ & 0.49 & $(0.24$ to 1.01$)$ \\
\hline $\begin{array}{l}\text { symptoms } \\
\text { Angioplasty } \\
\text { Bypass surgery } \\
\text { Angioplasty and bypass surgery } \\
\text { Reinfarction }\end{array}$ & $\begin{array}{r}13(6 \cdot 3) \\
9(2 \cdot 5) \\
1(0 \cdot 3) \\
1(0 \cdot 3) \\
15(4 \cdot 1)\end{array}$ & $\begin{array}{r}2(1 \cdot 1) \\
9(2 \cdot 5) \\
10(2 \cdot 8) \\
1(0 \cdot 3) \\
14(3 \cdot 9)\end{array}$ & $\begin{array}{l}0 \cdot 18 \\
1.03 \\
7 \cdot 22 \\
1 \cdot 03 \\
0 \cdot 96\end{array}$ & $\begin{array}{l}(0.05 \text { to } 0.69) \\
(0.43 \text { to } 2.50) \\
(1.17 \text { to } 4.09) \\
(0.11 \text { to } 9 \cdot 86) \\
(0.48 \text { to } 1.94)\end{array}$ \\
\hline
\end{tabular}

^207 Patients allocated to receive placebo, 179 patients allocated to receive recombinant plasminogen activator.

TABLE III-Clinical events during three month follow up in patients allocated to receive placebo or plasminogen activators. Figures are cumulative numbers (percentages) of patients

\begin{tabular}{|c|c|c|c|c|}
\hline & $\begin{array}{l}\text { Placebo } \\
(\mathrm{n}=366)\end{array}$ & $\begin{array}{c}\text { Recombinant } \\
\text { plasminogen } \\
\text { activator } \\
(\mathbf{n}=355)^{\star}\end{array}$ & $\begin{array}{l}\text { Rate } \\
\text { ratio }\end{array}$ & $\begin{array}{c}95 \% \\
\text { Confidence } \\
\text { interval }\end{array}$ \\
\hline \multicolumn{5}{|l|}{ Deaths: } \\
\hline All patients & $29(7 \cdot 9)$ & $18(5 \cdot 1)$ & 0.64 & $(0 \cdot 37$ to $1 \cdot 13)$ \\
\hline $\begin{array}{l}\text { Patients treated }<3 \text { hours after onset of } \\
\text { symptoms } \dagger\end{array}$ & $17(8 \cdot 2)$ & $6(3 \cdot 4)$ & 0.41 & $(0.17$ to 0.98$)$ \\
\hline Reinfarction & $23(6 \cdot 2)$ & $21(5.9)$ & 0.94 & $(0.53$ to 1.66$)$ \\
\hline Angioplasty & $16(4 \cdot 4)$ & $22(6 \cdot 2)$ & 1.42 & $(0.77$ to 2.64$)$ \\
\hline Bypass surgery & $17(4 \cdot 6)$ & $32(9 \cdot 0)$ & 1.94 & $(1.11$ to 3.41$)$ \\
\hline Angioplasty and bypass surgery & $2(0.5)$ & $2(0 \cdot 6)$ & 1.03 & $(0.18$ to $5 \cdot 84)$ \\
\hline
\end{tabular}

$\dagger 207$ Patients allocated to receive placebo, 179 patients allocated to receive recombinant plasminogen activator experimental infusion was started within three hours after the onset of symptoms (207 controls and 179 allocated to receive plasminogen activator) the reduction in mortality was $82 \%(-95$ to -31$)$ at 14 days and $59 \%(-83$ to -2$)$ at three months.

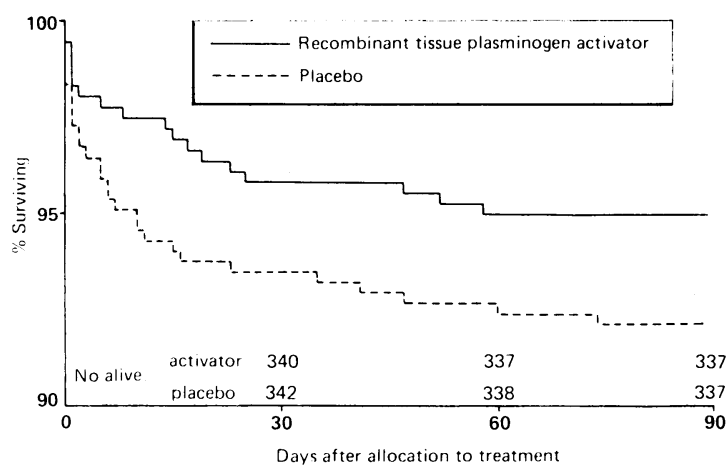

Survival to 90 days after allocation to receive recombinant tissue plasminogen activator $(n=355)$ or placebo $(n=366)$

Cardiovascular complications occurred less commonly in the treatment group. In particular the incidence of shock, ventricular fibrillation, and pericarditis was lower in this group than in the controls. Angioplasty or coronary artery bypass, or both, were performed in a higher percentage of patients in the thrombolysis group during the three month follow up.

On the other hand, complications of bleeding were more common with plasminogen activator. Most were of little importance. In five patients ( $1 \cdot 4 \%)$, however, intracranial bleeding occurred within three days after the infusion of plasminogen activator; one died whereas two recovered without neurological deficit. Table IV summarises all cases of intracranial events. In one patient receiving plasminogen activator (case 6) intracranial haemorrhage and death occurred on the 15th day, 12 hours after treatment of reocclusion with angioplasty and intravenous streptokinase. Three additional strokes occurred, one documented cerebral infarct in the treatment group (case 7) and two in the placebo group (cases 8 and 9), in which computed tomography had not been performed. Gastrointestinal bleeding was fairly uncommon in both groups.

TABLE IV-Details of clinical course and outcome in cases of cerebrovascular accident during treatment with recombinant plasminogen activator or placebo

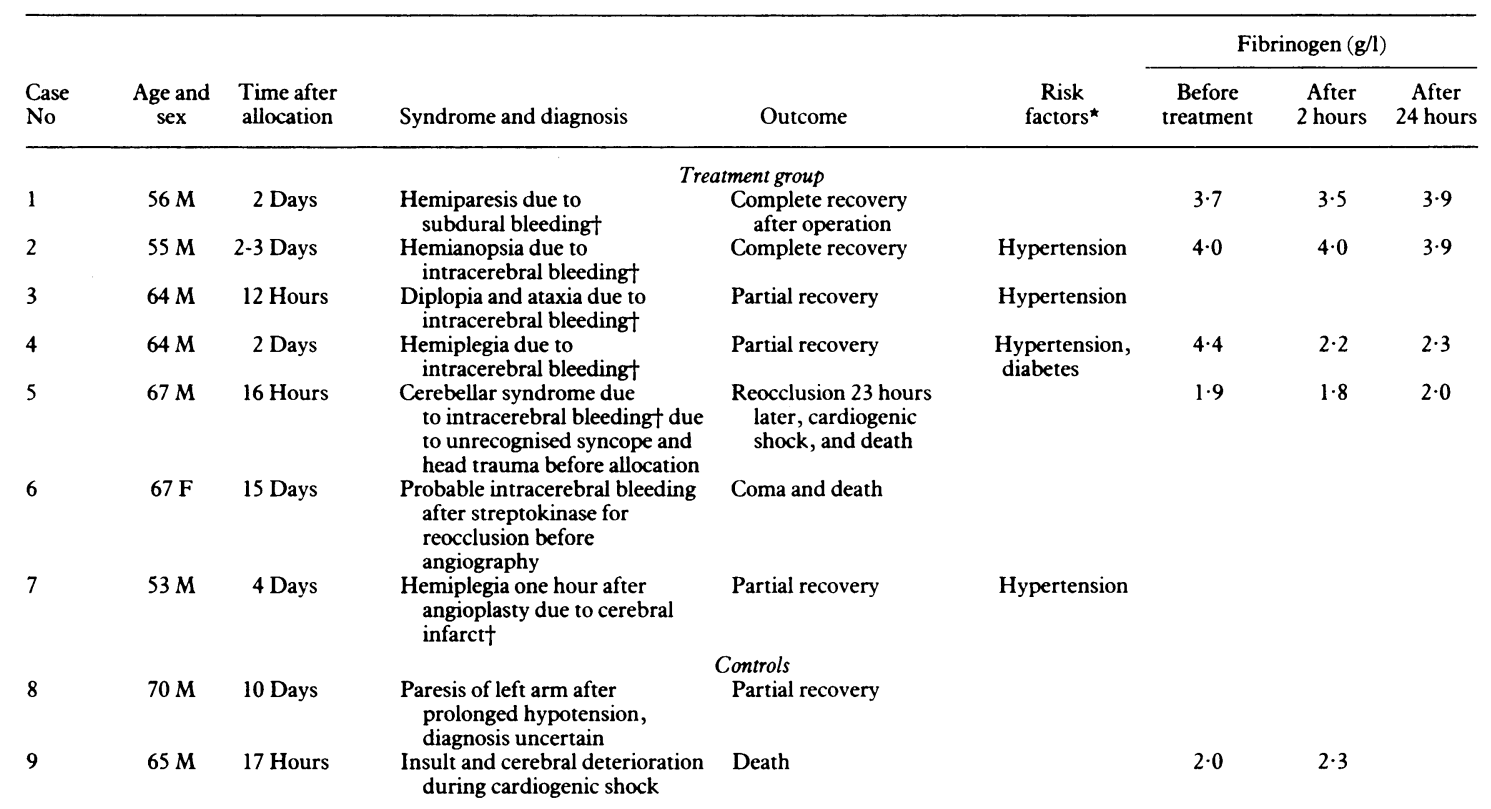

*Hypertension and diabetes.

tConfirmed by computed tomography. 
SIZE OF INFARCT

Cumulative release of $\alpha$ hydroxybutyrate dehydrogenase into plasma up to 72 hours could be determined from complete data in 618 patients. In 37 this value was extrapolated from data at 48 and 36 hours, and in 43 it was estimated from a single measurement of plasma $\alpha$ hydroxybutyrate dehydrogenase activity. The values of aspartate aminotransferase activity were used to estimate release of $\alpha$ hydroxybutyrate dehydrogenase up to 72 hours in four patients. Thus for 702 patients a value for release of the enzyme at 72 hours could be calculated. Median ( $90 \%$ range) values in the controls and treated patients were 867 (123-2143) U/l and 697 (119-1889) $\mathrm{U} / 1$ respectively. The figures indicate a significant reduction in the size of infarct of $20 \%(2 p=$ 0.0018 ) with plasminogen activator.

\section{ANGIOGRAPHIC FINDINGS}

Angiography could not be performed in 22 patients $(6 \%)$ allocated to receive plasminogen activator and in $30(8 \%)$ controls, including 10 treated patients and 20 controls who died before catheterisation. Other reasons for not performing the procedure were: cardiovascular complications (four in treatment group and two controls), patient refusal (six in treatment group and seven controls), non-cardiovascular complications (one in treatment group), or organisational and technical problems (one in both groups). In 14 patients $(4 \%)$ allocated to receive recombinant tissue plasminogen activator and in 17 controls (5\%) angiography was performed outside the chosen time interval because of cardiovascular complications (five patients in treatment group and four controls), non-cardiovascular clinical reasons (three patients in treatment group and one control), or organisational problems (six patients in treatment group and 12 controls).

Table $\mathrm{V}$ shows the patency of the affected vessel 10-22 days after the experimental treatment. A high

TABLE $\mathrm{V}$-Angiographic findings in patients allocated to receive placebo or plasminogen activator 10-22 days after admission

\begin{tabular}{lcc}
\hline & $\begin{array}{c}\text { Placebo } \\
(\mathrm{n}=366)\end{array}$ & $\begin{array}{c}\text { Recombinant } \\
\text { plasminogen } \\
\text { activator } \\
(\mathrm{n}=355)\end{array}$ \\
\hline Patency of affected vessel $^{\star}$ & $(\mathrm{n}=336)$ & $(\mathrm{n}=333)$ \\
$\quad$ Grade 0 & $58(17 \cdot 3)$ & $37(11 \cdot 1)$ \\
Grade 1 & $17(5 \cdot 1)$ & $19(5 \cdot 7)$ \\
Grade 2 & $38(11 \cdot 3)$ & $28(8 \cdot 4)$ \\
Grade 3 & $221(65 \cdot 8)$ & $247(74 \cdot 2)$ \\
Undetermined & $2(0 \cdot 6)$ & $2(0 \cdot 6)$ \\
Mean (SD) ejection fraction (\%) & $(\mathrm{n}=288)$ & $(\mathrm{n}=289)$ \\
Mean (SD) left ventricular volumes (ml) & $48 \cdot 5(11 \cdot 3)$ & $50 \cdot 7(10 \cdot 9)$ \\
$(\mathbf{n}=283)$ & $(\mathrm{n}=282)$ \\
End diastolic & $124 \cdot 2(34 \cdot 6)$ & $118 \cdot 2(35 \cdot 2)$ \\
End systolic & $65 \cdot 6(29 \cdot 7)$ & $59 \cdot 8(28 \cdot 1)$ \\
\hline
\end{tabular}

*According to grades of perfusion in the thrombolysis in myocardia infarction trial: $0=$ non-perfusion; $1=$ penetration with minimal perfusion (contrast fails to opacify entire coronary bed distal to the stenosis for the duration of filmin); $2=$ tire cor the duration of filming); $2=$ partial perfusion (contrast opacifies the entire coronary bed distal to the stenosis; the rate of entry or clearance or both, is, however, slower in coronary bed distal to the obstruction than in comparable (filling and clearance of contrast as rapid in coronary bed distal to stenosis as in other coronary beds).

percentage of patent (grades of perfusion 2 and 3 according to the criteria of the thrombolysis in myocardial infarction trial) coronary arteries was found in both groups: $77 \%$ in the controls and $83 \%$ in the thrombolysis group. The vessel could not be identified in 26 treated patients and in 11 control patients, in whom angiography was performed.

Left ventricular angiograms that were suitable for quantitative analysis were obtained in $577(80 \%)$ of the recruited patients. The ejection fraction was significantly greater by $2 \cdot 2 \%(95 \%$ confidence interval 0.3 to 4.0 ), in the treated group than the controls $(50.7 \% v 48.5 \%)$. The end diastolic volume was $6.0 \mathrm{ml}$
$(-0.2$ to -11.9$)$ smaller and the end systolic volume $5.8 \mathrm{ml}(-0.9$ to -10.6$)$ smaller in the thrombolysis group than in the control (table V).

\section{COAGULATION TESTS}

In a subset of 140 patients allocated to receive plasminogen activator the median ( $90 \%$ range) value for circulating fibrinogen at the start of infusion was $2 \cdot 4(1 \cdot 5-4 \cdot 3) \mathrm{g} / \mathrm{l}$, after 120 minutes $1 \cdot 9(0 \cdot 6-3 \cdot 3) \mathrm{g} / \mathrm{l}$, and after 24 hours $2 \cdot 2(0 \cdot 9-3 \cdot 5) \mathrm{g} / \mathrm{l}$. The corresponding values for 143 controls were $2.5(1 \cdot 1-4 \cdot 0) \mathrm{g} / \mathrm{l}, 2.5$ $(1 \cdot 3-3 \cdot 9) \mathrm{g} / \mathrm{l}$, and $3 \cdot 1(1 \cdot 3-4 \cdot 6) \mathrm{g} / \mathrm{l}$. Fibrin(ogen) degradation products rose from $1(1-17) \mu \mathrm{g} / \mathrm{ml}$ before infusion to $16(2-145) \mu \mathrm{g} / \mathrm{ml}$ after 120 minutes and to 6 $(1-64) \mu \mathrm{g} / \mathrm{ml}$ after 24 hours in the treated group and from $2(1-24) \mu \mathrm{g} / \mathrm{ml}$ to $2(1-39) \mu \mathrm{g} / \mathrm{ml}$ after 120 minutes and to $2(1-36) \mu \mathrm{g} / \mathrm{ml}$ after 24 hours in the controls.

\section{Discussion}

In this randomised, double blind, placebo controlled trial intravenous administration of recombinant plasminogen activator within five hours after the onset of symptoms was associated with limitation of the size of infarct, preservation of left ventricular function, and lower mortality. The limitation of the size of infarct measured from myocardial release of $\alpha$ hydroxybutyrate dehydrogenase was $20 \%$. Smaller infarcts were also shown after intravenous ${ }^{210}$ and intracoronary streptokinase. ${ }^{23}$ The limitation of enzymatic infarct size in this trial was associated with preserved left ventricular function as measured by a higher angiographic ejection fraction of $2 \cdot 2 \%$ and by smaller left ventricular end diastolic and end systolic volumes. Several studies have reported a $2 \cdot 9-6 \%$ higher ejection fraction after intravenous streptokinase. ${ }^{2-7}$ Furthermore, a significant improvement in ejection fraction has also been shown in patients with a first myocardial infarction and in those with anterior infarction in two placebo controlled trials of anisoylated plasminogen streptokinase activator complex..$^{11}$ Three placebo controlled trials with much smaller numbers of patients have shown a 6-7\% higher ejection fraction in patients treated with intravenous plasminogen activator. The exclusion of patients with a previous infarction together with the earlier administration of activator (less than $2 \frac{1}{2}$ hours) after the onset of symptoms in one trial, ${ }^{14}$ and the possible interaction of reperfusion and angioplasty $^{13}$ and a larger proportion of patients with anterior infarction assigned to active treatment ${ }^{15}$ in the other, might explain the greater difference in ventricular function in these trials. As in two other studies with streptokinase ${ }^{24}$ the end diastolic and end systolic volumes were significantly smaller in patients allocated to receive plasminogen activator. These findings suggest that early reperfusion not only improves contractile function but also prevents or at least limits expansion of the infarct and cardiac dilatation. Limitation of expansion of the infarct and cardiac dilatation may be even more important as ventricular volumes have a greater predictive value for survival after infarction than ejection fraction. ${ }^{25}$

Although this trial was not designed as a study of mortality, the administration of plasminogen activator was associated with improved short term survival. Despite low mortality in the controls mortality was reduced in patients treated with plasminogen activator from $5 \cdot 7 \%$ to $2 \cdot 8 \%$ at 14 days and from $7 \cdot 9 \%$ to $5 \cdot 1 \%$ at three month follow up. In patients treated within three hours after the onset of symptoms mortality decreased from $6 \cdot 3 \%$ to $1 \cdot 1 \%$ at 14 days and from $8 \cdot 2 \%$ to $3 \cdot 4 \%$ after three months. Mortality after treatment with plasminogen activator in this trial is close to that recently reported by us for patients similarly selected and treated ${ }^{26}$ and is the lowest reported so far in large 
thrombolysis trials. Mortality in the controls was low when compared with other studies of thrombolytic treatment $(13.0 \%$ at 21 days in the Gruppo Italiano per lo Studio della Streptochinasi nell' Infarto Miocardico trial $^{1}, 12 \cdot 0 \%$ at five weeks in the second international study of infarct survival, ${ }^{8}$ and $12 \cdot 2 \%$ at 30 days in the anistreptase intervention mortality study ${ }^{9}$ ). This is unlikely to have been caused by selection of low risk patients as the electrocardiographic entry criteria were more stringent than in the other studies ${ }^{19}$ and patients with cardiogenic shock were not excluded. All patients in our study were treated with low dose aspirin and heparin, which may have contributed to the low mortality in the controls. ${ }^{8}$ The reduction in mortality despite the low mortality in the controls supports the efficacy of treatment with plasminogen activator.

In addition to reduced mortality, the incidence of cardiovascular complications such as shock, ventricular fibrillation, and pericarditis was considerably lower in the treated patients. The reduced cardiovascular morbidity and mortality in conjunction with the reduction in the size of infarct, the smaller cardiac volumes, and the preservation of contractile function suggest a substantial saving of ischaemic myocardium as a result of the early administration of plasminogen activator.

Despite a moderate decrease in fibrinogen concentration five out of the 355 patients given plasminogen activator had an intracranial haemorrhage after the infusion (table IV). This incidence of intracranial bleeding of $1 \cdot 4 \%(95 \%$ confidence interval $0 \cdot 2$ to $2 \cdot 7)$ in the present study is higher than the $0.3 \%$ incidence (one patient out of 367 treated with plasminogen activator) reported in a trial by the European Study Group. ${ }^{26}$ In this twin study the entry criteria; treatment regimens with plasminogen activator, heparin, and aspirin; and the registration of events were identical. When the data of these two trials are combined the total incidence of intracranial bleeding is six patients out of $722(0 \cdot 8 \%(0 \cdot 2$ to $1 \cdot 5))$. Out of 3768 patients treated with $80-120 \mathrm{mg}$ single chain recombinant plasminogen activator from the same source as ours up to summer 1987 , intracranial bleeding occurred in $0.4 \%(0.2 \%$ to $0.6 \%) .{ }^{27}$ The number of patients with gastrointestinal or other serious bleeding and the number of blood transfusions given were small. Whether the concomitant administration of heparin and aspirin is partly responsible for the bleeding complications in patients treated with plasminogen activator is unknown and will be the subject of a future trial of our study group.

In conclusion, the intravenous infusion of plasminogen activator over three hours in addition to heparin and aspirin, within five hours after the onset of an acute myocardial infarction, has a beneficial effect on the size of infarct, left ventricular function, early survival, and cardiovascular morbidity, but at a cost of an increased risk of bleeding.

We thank Dr W Feuerer and the staff of Dr Karl Thomae $\mathrm{GmbH}$, for their help in preparing the trial medication and Mrs Agnes Goethuys for her secretarial help.

1 Gruppo Italiano per to Studio della Streptochinasi nell' Infarto Miocardico (GISSI). Effectiveness of intravenous thrombolytic treatment in acute (GISSI). Effectiveness of intravenous throm
myocardial infarction. Lancet 1986;i:397-401.

2 ISAM Study Group. A prospective trial of intravenous streptokinase in acute myocardial infarction (ISAM). Mortality, morbidity and infarct size at 21 days. N Engl f Med 1986;314:1456-71.

3 Schröder R, Neuhaus KL, Leizorovicz A, et al. A prospective placebocontrolled double-blind multicenter trial of intravenous streptokinase in acute myocardial infarction (ISAM): long-term mortality and morbidity. f Am Coll Cardiol 1987;9:197-203.

4 Kennedy JW, Martin GV, Davis KB, et al. The Western Washington intravenous streptokinase in acute myocardial infarction randomized trial. Circulation 1988:77:345-52.

5 White HD, Norris RM, Brown MA, et al. Effect of intravenous streptokinase on left ventricular function and early survival after acute myocardial on left ventricular function and early

6 Olson HG, Butman SM, Piters KM, et al. A randomized controlled trial of in acue myocardial infarction. Am Heart $y$ 1986;111:1021-9.

Bassand JP, Faivre R, Becque $\mathrm{O}$, et al. Effects of early high-dose streptokinas intravenously on left ventricular function in acute myocardial infarction. Am f Cardiol 1987;60:435-9.

8 ISIS-2 Collaborative Group. Randomised trial of intravenous streptokinase, oral aspirin, both, or neither among 17187 cases of suspected acute myocardial infarction: ISIS-2. Lancet 1988;ii:349-60.

9 AIMS Trial Study Group. Effect of intravenous APSAC on mortality afier acute myocardial infarction: preliminary report of a placebo-controlled clinical trial. Lancet 1988; ; $545-9$.

10 Bassand JP, Machecourt J, Cassagnes T, et al. A multicenter double-blind trial of intravenous APSAC versus heparin in acute myocardial infarction. Preliminary report of the APSIM study. Circulation 1987;76(suppl IV): IV-121.

11 Eminase Study Group. Intravenous eminase in acute myocardial infarction. Results of the German Eminase Multicenter Trial (GEMT). Circulation 1987;76(suppl IV):IV-122.

12 Jang IK, Vanhaecke J, De Geest H, Verstraete M, Collen D, Van de Werf F Coronary thrombolysis with recombinant tissue-type plasminogen activator: patency rate and regional wall motion after 3 months. $\mathcal{J}$ Am Coll Cardiol 1986;8:1455-60.

3 Guerci AD, Gerstenblith G, Brinker JA, et al. A randomized, placebocontrolled, double-blind trial of intravenous tissue plasminogen activator for acute myocardial infarction with subsequent randomization to elective coronary angioplasty. $N$ Engl f Med 1987;317:1613-8.

14 O'Rourke M, Baron D, Keogh A, et al. Limitation of myocardial infarction by early infusion of recombinant tissue-type plasminogen activator. Circulation $1988 ; 77: 1311-5$.

15 National Heart Foundation of Australia Coronary Thrombolysis Group. Coronary thrombolysis and myocardial salvage by tissue plasminogen activator given up to 4 hours after onset of myocardial infarction. Lancet activator given

16 Van de Werf F, Vanhaecke J, De Geest G, Verstraete M, Collen D. Coronary thrombolysis with recombinant single-chain urokinase-type plasminogen activator in patients with acute myocardial infarction. Circulation 1986;74: 1066-70

17 The TIMI Study Group. The thrombolysis in myocardial infarction (TIMI) trial. N Engl f Med 1985;312:932-6.

18 Verstraete M, Bernard R, Bory M, et al. Randomised trial of intravenous recombinant tissue-type plasminogen activator versus intravenous streptokinase in acute myocardial infarction. Report from the European Cooperative Study Group for Recombinant Tissue-type Plasminogen Activator. Lancet 1985; i:842-7.

19 Willems GM, Muijtiens AMM, Lambi FHH, Hermens WT. Estimation of circulatory parameters in patients with acute myocardial infarction. Significance for calculation of enzymatic infarct size. Cardiovasc Res 1979;13: 578-87.

20 Van de Laarse A, Hermens WT, Hollaar L, et al. Assessment of myocardial damage in patients with acute myocardial infarction by serial measurement of serum alpha-hydroxybutyrate dehydrogenase levels. Am Heart $f 1984$; 107:248-60.

21 Pocock SJ. Clinical trials: a practical approach. Chichester: Wiley and Sons, 1984:209.

22 Miettinen OS, Nurminen M. Comparative analysis of two rates. Stat Med 1985;4:213-26.

23 Simoons ML, Serruys PW, van den Brand M, et al. Improved survival after early thrombolysis in acute myocardial infarction: a randomised trial by the Interuniversity Cardiology Institute in The Netherlands. Lancel 1985;ii: 578-82.

24 Serruys PW, Simoons ML, Suryapranata $\mathbf{H}$, et al. Preservation of global and regional left ventricular function after early thrombolysis in acute myocardial infarction. $\mathcal{A}$ Am Coll Cardiol 1986;7:729-42.

25 White HD, Norris RM, Brown MA, Brandt PWT, Whitlock RML, Wild CJ. Left ventricular end-systolic volume as the major determinant of survival after recovery from myocardial infarction. Circulation 1987;76:44-51.

26 Simoons ML, Arnold AER, Betriu A, et al. Thrombolysis with tissue plasminogen activator in acute myocardial infarction: no additional benefit of immediate PTCA. Lancet 1988;i:197-202.

27 Food and Drug Administration. Basis of approval of alteplase. Bethesda FDA, 1986: 15. (Summary 86-0236.

(Accepted 23 August 1988)

EUROPEAN COOPERATIVE STUDY GROUP FOR RECOMBINANT TISSUE TYPE PLASMINOGEN ACTIVATOR

Participating clinics and investigators were Universitair Ziekenhuis Gasthuisberg, Leuven: $H$ De Geest, F Van de Werf, A Beernaert; H Hartkliniek, Neerpelt: A Van Dorpe; OCMW St Elisabeth, Turnhout: H Lesseliers, D Engelaar; St Jozefkliniek, Ostend: R Stroobandt, G Holvoet; H Hartziekenhuis, Roeselare: R Beeuwsaert, D Clement; St Elisabethziekenhuis, Geel: J Schurmans, M Vermeire; Imelda Ziekenhuis, Bonheiden: L Hermans, G Verstreken; St Jozefziekenhuis, St Truiden: J Beckers, H Robijns; St Elisabethziekenhuis, Herentals: S De Schepper; H Hartziekenhuis, Tienen: L De Wolf, $\mathrm{H}$ Van der Linden; St Norbertusziekenhuis, Duffel: U Van Walleghem; Virga Jesse Ziekenhuis, Hasselt: R Geukens, J Maris; Onze Lieve Vrouw Kliniek, Tongeren: F Gielen; Leyenburg Ziekenhuis, The Hague: G A van der Kley; van Dam-Bethesda Ziekenhuis, Rotterdam: JW Deckers; Kantonsspital, Basle: M Pfisterer, F Burkart; Centre de Reanimacio Cardiaca-Unitat Coronaria, Manresa: LL Jodar, PX Boada P, EJ Corrons; Hospital Mutua de Terrassa: L Saenz, S Quintana, A Alvarez, JM Nava, M Alvarez; Royal Infirmary, Edinburgh: D de Bono, D Ettles; Freeman Hospital, Newcastle upon Tyne: DS Reid, M Been; Stobhill General Hospital, Glasgow: WS Hillis, KJ Hogg, RS Hornung, JMA Burno, FG Dunn, AP Rae, M 
Sandler; Medisch Centrum Alkmaar: C Burgersdijk, J Ruiter; St Franciscus Ziekenhuis, Roosendaal: RJ Bos; Akademika Sjukhuset, Uppsala: B Lagerqvist; Hospital de la Princesa, Madrid: C Romero, X Ruiz-Ocana, A Reyes; Hospital de la Santa Creu i Sant Pau, Barcelona: J Garcia-Moll, X GarciaPicart.

Members of the steering committee were M Verstraete (chairman), F Van de Werf (Leuven), DP de Bono (Edinburgh), $\mathrm{R}$ von Essen (Munich), RJ Lennane, I Welbers (Ingelheim), J Lubsen, PW Serruys, ML Simoons (Rotterdam), W Rutsch (Berlin), and A Vahanian (Paris).

Members of the data monitoring and ethical committee were $\mathrm{J}$ Hampton (Nottingham), DG Julian (Newcastle upon Tyne), W Schaper (Bad Nauheim), L Wilhelmsen (Gothenburg), and D Wood (Southampton).

Members of the angiography assessment group were DP de Bono (chairman, Edinburgh), WS Hillis (Glasgow), DS Reid (Newcastle upon Tyne), W Rutsch (Berlin), PW Serruys
(Rotterdam), R Uebis (Aachen), and A Vahanian (Paris). Members of the ECG assessment group were JL Willems (Leuven), W Schmidt, and R Dörr (Aachen).

Members of the exercise test assessment group were $\mathrm{R}$ von Essen (Munich) and JM Detry (Brussels).

Members of the radionuclide assessment group were J Vanhaecke, L Mortelmans (Leuven), and J Melin (Brussels).

Members of the data coordinating centre were AER Arnold, $M$ Bokslag, EPM Bos-Wolvers, RW Brower, I van Oosterom-de Waard, KM Hoolboom-Neissen, HF Eldering-Gerritsen, and J Lubsen (Rotterdam).

Members of the core laboratory for enzyme determination were WT Hermens, GM Willems (Maastricht).

Members of the core laboratory for quantitative angiography were PW Serruys, AER Arnold, KM Hoolboom, and C Tirtaman (Rotterdam).

Members of the central coagulation laboratory were D Collen and HR Lijnen (Leuven).

\title{
Consequences of fetomaternal haemorrhage after intrauterine transfusion
}

\author{
Umberto Nicolini, Neil K Kochenour, Pantaleo Greco, Elizabeth A Letsky, Robert D Johnson, \\ Marcela Contreras, Charles H Rodeck
}

\begin{abstract}
Fetomaternal haemorrhage was studied after 68 consecutive fetal intravascular transfusions performed in 20 patients with $R h$ isoimmunisation. $\alpha$ Fetoprotein concentration was assayed in maternal blood taken before, and immediately after each transfusion and three and 24 hours later. An increase of $50 \%$ or more in the concentration in any of the samples after transfusion was considered to indicate fetomaternal haemorrhage. Fetal $\alpha$ fetoprotein concentration in blood sampled before transfusion was also assayed and the amount of fetomaternal haemorrhage calculated. Fetomaternal haemorrhage occurred in 21 of 32 patients with an anterior placenta and in six of 36 with a posterior or fundal placenta. The mean estimated volume of haemorrhage was $2.4 \mathrm{ml}$, which was on average equal to $3 \cdot 1 \%$ of the total fetoplacental blood volume. When the volume of fetomaternal haemorrhage at the first transfusion was greater than $1 \mathrm{ml}$ there was a greater increase in maternal $\mathbf{R h}(D)$ antibody titres and a greater fall in fetal packed cell volume.

Sampling of fetal blood should not be routinely done early in patients with $\mathrm{Rh}$ isoimmunisation, and intrauterine transfusion should be delayed as long as possible. Sampling sites other than the placental cord insertion reduces the risk of fetomaternal haemorrhage.
\end{abstract}

\section{Introduction}

Intravascular blood transfusion has been advocated as the best approach to managing fetuses with severe $\mathrm{Rh}$ haemolytic disease..$^{1-5}$ This procedure allows precise assessment of the degree of fetal anaemia and of the volume of $\mathrm{Rh}$ negative donor blood that must be transfused to raise the fetal haemoglobin concentration and packed cell volume to normal values. Two different procedures are commonly used: fetoscopy and ultrasound guided needling of the umbilical cord, the intrahepatic tract of the umbilical vein, or the heart under ultrasonic guidance.

Rodeck et al achieved good results with fetoscopy but Mackenzie et al did not, ${ }^{6}$ and transabdominal needling is now used by most centres as it is easier and safer. A fetal mortality of about $1 \%$ was reported by Daffos et al in a large series of diagnostic samplings,? though the rate is probably higher in fetuses with $\mathrm{Rh}$ haemolytic disease as the procedure is usually done several times. Reports of several series have claimed that this technique is the first choice in the management of patients with $\mathrm{Rh}$ isoimmunisation. Direct access to the fetal circulation avoids the problems of indirect tests such as spectrophotometry of the amniotic fluid in evaluating the severity of the disease. ${ }^{*}$

Transplacental ultrasound guided needling may result in fetomaternal haemorrhage, which in cases of $\mathrm{Rh}$ isoimmunisation may increase the severity of the disease by enhancing the maternal immunological response to fetal antigens. Fetomaternal haemorrhage has been investigated after amniocentesis ${ }^{910}$ and fetoscopy ${ }^{11}$ but not after transabdominal needling. We therefore studied the occurrence of fetomaternal haemorrhage in patients undergoing intrauterine transfusions for $\mathrm{Rh}$ haemolytic disease by transabdominal needling. The severity of the haemorrhage was related to the site of sampling and to changes in maternal antibody titres and fetal packed cell volumes after transfusion.

\section{Patients and methods}

Fetomaternal haemorrhage was studied after 68 consecutive fetal intravascular transfusions performed from November 1986 to June 1987 in 20 patients with $\mathrm{Rh}$ isoimmunisation. Fourteen procedures were the first performed in each patient and 54 were subsequent ones. Gestational ages ranged between 18 and 33 weeks. All the transfusions were performed by transabdominal needling under continuous ultrasonic control with a 20 gauge spinal needle. Fetal blood ( 2 $\mathrm{ml}$ ) was taken for immediate estimation of packed cell volume (Coulter Channelyzer) before transfusion of packed erythrocytes from $\mathrm{Rh}$ negative donors, which had been cross matched with maternal blood.

The site of sampling and transfusion was the placental cord insertion in 47 procedures and the intrahepatic vein, fetal umbilical cord insertion, or free cord in the remaining 21 . The umbilical artery was not sampled. The placenta was mainly anterior in 32 patients and posterior or fundal in 36 . 